\title{
Distribution of Al-, Fe- and Mn-pools and their correlation in soils from two acid deposition small catchments in Hunan, China
}

\author{
Nandong Xue ${ }^{\mathrm{a}, *}$, Hans Martin Seip ${ }^{\mathrm{b}}$, Jinheng Guo ${ }^{\mathrm{c}}$, Bohan Liao ${ }^{\mathrm{a}}$, Qingru Zeng ${ }^{\mathrm{a}}$ \\ ${ }^{a}$ College of Resources and Environmental Sciences, Hunan Agricultural University, Changsha 410128, China \\ ${ }^{\mathrm{b}}$ Department of Chemistry, University of Oslo, P.O. Box 1033, Blindern 0315 Oslo, Norway \\ ${ }^{\mathrm{c}}$ Research Center for Eco-Environmental Sciences, Chinese Academy of Sciences, 18 Shuangqing Road, P.O. Box 2871, Beijing 100085, China
}

Received 18 November 2005; received in revised form 10 April 2006; accepted 13 April 2006

Available online 5 June 2006

\begin{abstract}
Distribution of Al-, Fe- and Mn-pools was investigated in five forest soil profiles (consisting of four horizons) in each of two Hunan catchments (BLT and LKS) where acid deposition has been considered critical. Al- and Fe-pools were higher in BLT than those in LKS, but Mn-pools much lower in BLT. Mn-pools vary from topsoils to bottom soils, but there are different trends for different Mn speciation. Al- and Fe-pools, except amorphous $\mathrm{Fe}_{\mathrm{ox}}$, were positively correlated to contents of soil organic matter (OM) showed by the loss on ignition in the two catchments. Accumulation of Al- and Fe-pools may occur in the area where soil organic matter was enriched (e.g. in top soil and rhizosphere soil). However, no direct correlation is observed between Mn and OM. Acidic atmospheric deposition may affect transforming among speciations of Al-, Fe- and Mn-pools and leaching of soil Al, Fe and Mn through formation of soluble organometal dissolved Al which was potentially toxic, increased. There were significant correlations between Al-pools complexes or change of oxidation-reduction conditions. $\mathrm{Mn}_{\mathrm{ex}}$ (exchangeable $\mathrm{Mn}$ ) and $\mathrm{Mn}_{\mathrm{ox}}$ (amorphous and organic $\mathrm{Mn}$ ) were highly linearly correlation with soil $\mathrm{pH}$ values at LKS but at BLT. Under acid deposition, the availability of the nutrient Fe increased with the amount of dissolved

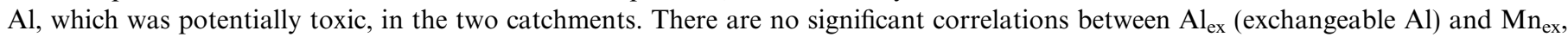
$\mathrm{Fe}_{\mathrm{ex}}$ (exchangeable $\mathrm{Fe}$ ) and $\mathrm{Mn}_{\mathrm{ex}}$ in this work, indicating potentially toxic $\mathrm{Mn}$ increase seldom accompanying with $\mathrm{Al}$ increase in the two catchments.
\end{abstract}

(c) 2006 Elsevier Ltd. All rights reserved.

Keywords: Small catchment; Soil; Al-pools; Fe-pools; Mn-pools; Acid deposition; Hunan

\section{Introduction}

Acid deposition, which is associated with sulphur dioxide $\left(\mathrm{SO}_{2}\right)$ and nitrogen oxide $\left(\mathrm{NO}_{x}\right)$ emissions, is an important environmental problem in China, particularly in southern regions (i.e. south of the Yangtze River). Hunan is among the provinces in China most seriously affected by acid deposition. Acid rain was first reported in Changsha (the capital of Hunan) in 1972 which has since become one of the most seriously acid rain polluted cities in China,

\footnotetext{
${ }^{*}$ Corresponding author. Tel.: +86 731 4618166; fax: +86 7314611473. E-mail address: ndxue@yahoo.com.cn (N. Xue).
}

with an average volume-weighted precipitation $\mathrm{pH}$ value below 4.5. In 2000, the annual average volume-weighted $\mathrm{pH}$ was 3.53 and the acid rain frequency (i.e. $\mathrm{pH}<5.6$ ) was $90 \%$ (SEPA, 2001).

Much information about effects of acid deposition has been obtained through catchment studies. Biogeochemical cycles of individual elements have been studied at the Hubbard Brook Experimental Forest (HBEF) in New Hampshire, USA since 1963 and at Solling in Germany since 1969, pioneering the use of the small catchment concept for understanding the processes in an ecosystem. Numerous other studies of small catchments were performed in the last two decades, mainly in connection with acid rain research in North America and Europe and include Probst 
et al. (1990), Driscoll et al. (1994), Likens et al. (2002), Van Breemen and Wright (2004) and Watmough et al. (2005). Recently there have also been such studies in China (Zhao et al., 2001; Shao, 2002; Xue et al., 2003). Several research programs have been conducted and great progress has been achieved in understanding the soil acidification process in Hunan in the recent decades. The studies include responses of Hunan forest soil to acidic input (Liao et al., 1998), mechanisms of sulfate adsorption in red soils in southern Hunan (Chen et al., 1995), buffering mechanism of Hunan soil (Liao and Li, 1989), and relative sensitivity of Hunan soils to acid deposition (Tao et al., 2002). The catchment scale studies on acid deposition in Hunan are conducted in CaiJiaTang (CJT) catchment (Shao, 2002) by the Integrated Monitoring Program on Acidification of Chinese Terrestrial Systems (IMPACTS, 2003), and in LinKeSuo (LKS) and BaiLuTang (BLT) catchments (Xue et al., 2003).

Acid precipitation and its precursors affect human health, materials and ecosystems (Rodhe et al., 1995). While surface water acidification is not believed to be a major problem in China, acidification of soil and soil water is likely to affect terrestrial ecosystems seriously in many areas including parts of Hunan (Chen et al., 1995; Liao et al., 1997; Seip et al., 1999). Potential effects of acid deposition on element biogeochemical cycles in forest soils could be summarized as follows: (1) increased rate of mineral weathering with base-cation release in soils (Fernandez, 1985); (2) enhanced fluxes of elements from atmospheric inputs (Raubuch et al., 1998); (3) facilitated base-cation leaching in soil profiles (Hendershot et al., 1992); and (4) decreased rate of organic matter (OM) decomposition resulting from altered soil enzyme activities, a consequence of toxic metal accumulation (Binkley, 1986).

The physico-chemical forms in which the metals exist are more important for environment than the total metal concentrations (Martin et al., 1987). The determination of extractable metals in soil is often used to gain an insight into chemical speciation. The toxicity of metals depends especially on their chemical forms rather than on their total elemental contents, and therefore, speciation studies increasingly gain importance. However, information about all these aspects is scarce in Hunan. The catchment scale studies on speciation of Aluminium ( $\mathrm{Al})$, Iron $(\mathrm{Fe})$ and Manganese (Mn) under acid deposition increasingly gain importance to understand and assess soil sensitivity to acidification and potential ecological damage.

In a former work (Xue et al., 2003), we reported the results of acid deposition and its effect on soil acidification in two Hunan small catchments. This paper focuses on the speciation of three metal elements ( $\mathrm{Al}, \mathrm{Fe}$ and $\mathrm{Mn})$ in the surface soils from the two small catchments where acid deposition has been considered critical. The potential effects of acid deposition on three elements in surface soils were evaluated with emphasis on the correlations among the three metal elements on a catchment scale. This may contribute to a better understanding of the present and future effects of acid deposition on elemental biogeochemistry in the forest ecosystem. This study results will provide new insights on the behavior and status of $\mathrm{Al}, \mathrm{Fe}$ and $\mathrm{Mn}$ elements in a small catchment scale.

\section{Catchment description}

Two acid sensitive small catchments, BLT and LKS, were selected in Hunan province for detailed studies. The BLT is located about $20 \mathrm{~km}$ east of Chenzhou $\left(25.78^{\circ} \mathrm{N}\right.$, $113.01^{\circ} \mathrm{E}$ ) at nearly $400 \mathrm{~m}$ a.s.l. BLT has on average 300 frost-free days a year. The annual average temperature is $16.9^{\circ} \mathrm{C}$ and the total annual rainfall is $1550 \mathrm{~mm}$. The main tree species are Chinese fir (Cunninghemia lanceolota) and Masson pine (Pinus massoniana). There are also a range of broad-leaf trees and bushes. The soil is in Ferric Acrisol in the FAO system and its parent material is granite. Kaolinite is the dominant clay mineral; there are also small amounts of vermiculite and illite. The LKS (about $100 \mathrm{~m}$ a.s.l) is located about $40 \mathrm{~km}$ east of Changsha $\left(28.2^{\circ} \mathrm{N}\right.$, $\left.113.1^{\circ} \mathrm{E}\right)$. It has an annual average temperature of

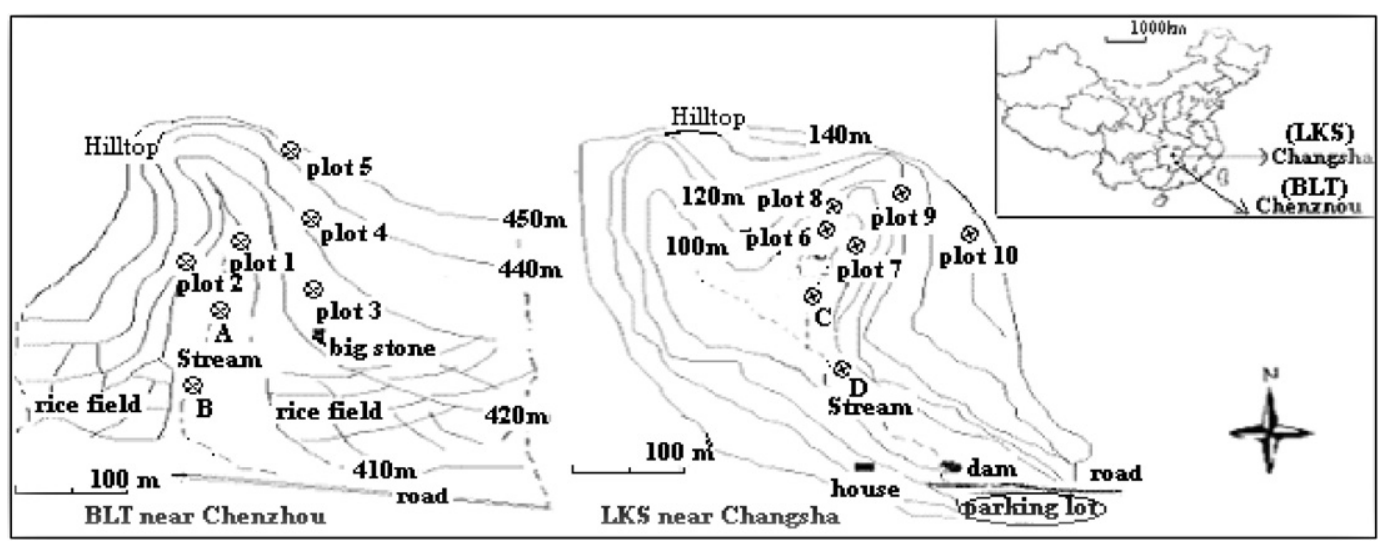

Fig. 1. Topographical map and sampling sites in BLT, near Chenzhou, and in LKS, near Changsha. (The plots 1-10 are soil sampling sites; A, B, C and D are the sampling sites for stream water; plots 1 and 7 are soil water sampling sites. The sampling sites for wet deposition, bulk deposition and throughfall were set up near plots 3 and 7.) 
$17.5^{\circ} \mathrm{C}$ and annual average precipitation of $1380 \mathrm{~mm}$. The soil is in Ferric Acrisol in the FAO system and its parent material is shale. Kaolinite is the dominant clay mineral; there are also small amounts of hydromica and biotite flakes. The main tree species is Chinese fir. Ten soil plots (five from each catchment) were selected for detailed studies in the two catchments (Fig. 1).

The water passing through the two catchments had been monitored. Wet deposition, throughfall, bulk deposition, soil water samples and stream water samples were collected from June 19, 2000 to June 19, 2002. Detailed descriptions of sampling equipment, procedures for sample collection and the analytical methods used in this investigation have been reported previously (Xue et al., 2003). At the BLT catchment, the volume-weighted $\mathrm{pH}$ in wet deposition for the study period was 4.54 . All samples were acidic $(\mathrm{pH}<5.6)$. In the LKS catchment, the volume-weighted $\mathrm{pH}$ for the period was $4.90 ; 80 \%$ of the events, corresponding to about $78 \%$ of the total precipitation amount, were acidic. Sulfate is the dominant anion and $\mathrm{SO}_{2}$ the major acid rain precursor. The volume-weighted sulfate concentrations in wet deposition were $174 \mu \mathrm{mol}_{\mathrm{c}} 1^{-1}$ and $152 \mu \mathrm{mol}_{\mathrm{c}} \mathrm{1}^{-1}$ for the study period at BLT and at LKS, respectively. We had estimated that the sum of bulk deposition were about $6.1 \mathrm{gS} \mathrm{m}^{-2} \mathrm{y}^{-1}$ at BLT and $5.3 \mathrm{gS} \mathrm{m}^{-2} \mathrm{y}^{-1}$ at LKS, respectively. And the sum of S depositions in throughfall were also estimated with $7.8 \mathrm{gS} \mathrm{m}^{-2} \mathrm{y}^{-1}$ at BLT and $6.6 \mathrm{gS} \mathrm{m}^{-2} \mathrm{y}^{-1}$ at LKS, with $1.7 \mathrm{gS} \mathrm{m}^{-2} \mathrm{y}^{-1}$ and $1.3 \mathrm{gS} \mathrm{m}^{-2} \mathrm{y}^{-1}$ higher than the sum of bulk deposition (Xue et al., 2003).

\section{Analyses and methods}

Soils from four generic horizons $(\mathrm{O}, \mathrm{A}, \mathrm{E}$ and $\mathrm{B})$ at the selected plots were sampled. (The depths of the soil generic horizons in the plots are included in Table 1.) After removing coarse fragments and root debris, the samples collected from individual soil profiles were air dried and passed through a $2 \mathrm{~mm}$ sieve prior to analyses. Chemical analyses were conducted partly at Department of Environmental Sciences, Hunan Agricultural University, and partly at Department of Chemistry, University of Oslo. Soil $\mathrm{pH}_{\mathrm{H}_{2} \mathrm{O}}$ was measured with a soil/solution ratio of 1:2 of air-dried soil and deionized water using a Ross ${ }^{\circledR}$ pH electrode (Robarge and Fernandez, 1986; ISO, 1994). Exchangeable cations were extracted using an un-buffered $\mathrm{BaCl}_{2}$ solution (Hendershot and Duquette, 1986). Metal cations $\left(\mathrm{Ca}^{2+}, \mathrm{Mg}^{2+}, \mathrm{Na}^{+}, \mathrm{K}^{+}, \mathrm{Fe}^{3+}, \mathrm{Mn}^{2+}\right.$ and $\left.\mathrm{Al}^{3+}\right)$ in the extracts were determined by ICP-AES (Inductively Coupled Plasma-Atomic Emission Spectrometry). The $\mathrm{pH}$ $\left(\mathrm{BaCl}_{2}\right)$ values measured with a Ross ${ }^{\circledR} \mathrm{pH}$ electrode gave $\mathrm{H}^{+}$in the extracts. The equivalent sum of exchangeable cations $\left(\mathrm{Mg}, \mathrm{Na}, \mathrm{K}, \mathrm{Al}, \mathrm{Mn}\right.$ and $\mathrm{Fe}$ in $0.1 \mathrm{M} \mathrm{BaCl}_{2}$ ) gave the effective cation exchange capacity $\left(\mathrm{CEC}_{\mathrm{e}}\right)($ Hendershot and Duquette, 1986). Soil organic matter (OM) was expressed by loss on ignition (LOI) determined by combustion at $550 \pm 50^{\circ} \mathrm{C}$ in a furnace for $24 \mathrm{~h}$ (Krogstad, 1992).

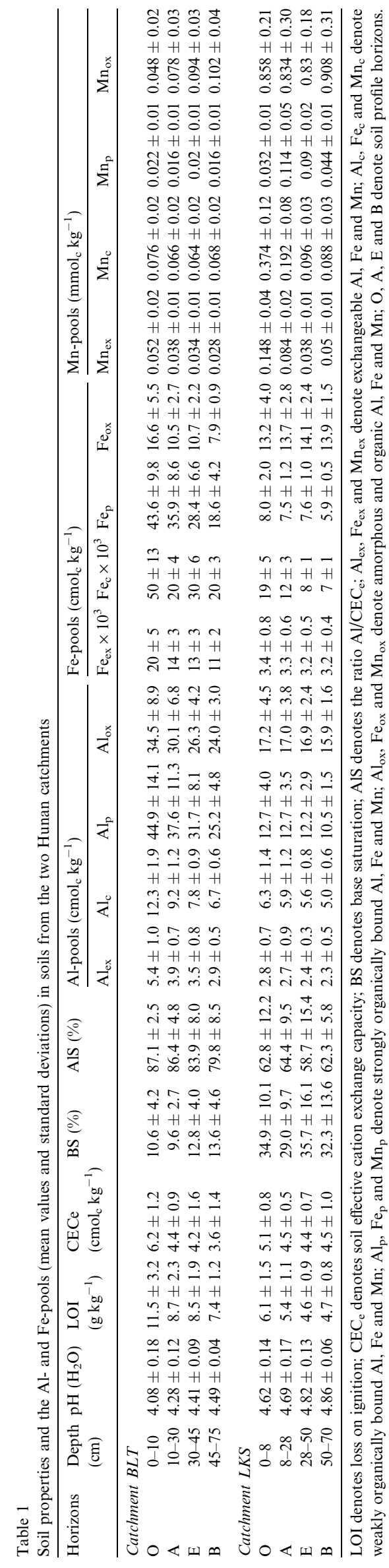


Al-, Fe- and $\mathrm{Mn}$-pools include exchangeable $\mathrm{Al}, \mathrm{Fe}$ and $\mathrm{Mn}\left(\mathrm{Al}_{\mathrm{ex}} \mathrm{Fe}_{\mathrm{ex}}\right.$, and $\left.\mathrm{Mn}_{\mathrm{ex}}\right)$, weakly organically bound $\mathrm{Al}, \mathrm{Fe}$ and $\mathrm{Mn}\left(\mathrm{Al}_{\mathrm{c}}, \mathrm{Fe}_{\mathrm{c}}\right.$ and $\left.\mathrm{Mn}_{\mathrm{c}}\right)$, strongly organically bound $\mathrm{Al}$, $\mathrm{Fe}$ and $\mathrm{Mn}\left(\mathrm{Al}_{\mathrm{p}}, \mathrm{Fe}_{\mathrm{p}}\right.$ and $\left.\mathrm{Mn}_{\mathrm{p}}\right)$ and amorphous and organic $\mathrm{Al}, \mathrm{Fe}$ and $\mathrm{Mn}\left(\mathrm{Al}_{\mathrm{ox}}, \mathrm{Fe}_{\mathrm{ox}}\right.$ and $\left.\mathrm{Mn}_{\mathrm{ox}}\right)$. The data for exchangeable $\mathrm{Al}, \mathrm{Fe}$ and $\mathrm{Mn}$ are generated in the $\mathrm{CEC}_{\mathrm{e}}$ determination described above. $\mathrm{Al}_{\mathrm{c}}, \mathrm{Fe}_{\mathrm{c}}$ and $\mathrm{Mn}_{\mathrm{c}}$ were extracted by cupric chloride $\left(\mathrm{CuCl}_{2}\right)$ electrolyte (Jou and Kamprath, 1979). $\mathrm{Al}_{\mathrm{p}}, \mathrm{Fe}_{\mathrm{p}}$ and $\mathrm{Mn}_{\mathrm{p}}$ were extracted using high $\mathrm{pH}(\mathrm{pH}=10)$ sodium pyrophosphate solution (Van Reeuwijk, 1995). $\mathrm{Al}_{\mathrm{ox}}, \mathrm{Fe}_{\mathrm{ox}}$ and $\mathrm{Mn}_{\mathrm{ox}}$ were extracted with an acid ammonium oxalate $\mathrm{H}_{2} \mathrm{C}_{2} \mathrm{O}_{4} /\left(\mathrm{NH}_{4}\right)_{2} \mathrm{C}_{2} \mathrm{O}_{4}$ solution (Mckeague and Day, 1966). Al, Fe and $\mathrm{Mn}$ in the extracts were determined by ICP-AES.

On the ICP-AES, the standard sample was run for every 7th sample, while for every 30th sample on the AAS. Standard calibration samples from NIVA (an ISO accredited chemical laboratory at Norwegian Institute for Water Research in Oslo, Norway) for $\mathrm{Ca}^{2+}, \mathrm{Mg}^{2+}, \mathrm{Na}^{+}, \mathrm{K}^{+}$ and $\mathrm{Al}^{3+}$ determination were also analyzed both on ICPAES and AAS. The average discrepancies for calibration samples are below $12.5 \%$. The relative deviations of $\mathrm{Fe}^{3+}$ and $\mathrm{Mn}^{2+}$ determination between ICP-AES and AAS were below $5 \%$. All our results of other ions were less than one standard deviation from the mean.

The intra-laboratory precision in the analyses of soil samples was checked by determining values of three sample replicates. The relative standard deviations (RSD, \%) among replicates were below $7.0 \%$. The uncertainties in the analyses were discussed in more detail in previous work (Liao et al., 1997, 1998).

All the glassware and polyethylene material used were previously soaked in diluted nitric and hydrochloric acids, then rinsed with deionized water obtained from a Millipore Milli-Q, Milli-Ro system (resistivity: $18 \mathrm{M} \Omega$ ).

\section{Results and discussions}

\subsection{Soil chemistry in the two catchments}

The soil $\mathrm{pH}$ values, $\mathrm{CEC}_{\mathrm{e}}$, base saturation (BS), aluminum saturation (AlS), LOI and Al-, Fe- and Mn-pools for ten forest soil profiles (four horizons from each) collected from the two Hunan catchments are summarized in Table 1 , with the mean and the standard error from each sampling site. The soil $\mathrm{pH}$ values in water were in the range 3.94-5.19 and $\mathrm{BS}$ varied from $6.9 \%$ to $51.8 \%$. In general $\mathrm{pH}$ increases with depth and is lower at BLT than at LKS, especially in the O-horizon. This is in agreement with the higher AlS and lower BS at BLT than at LKS (see Table 1). As commonly found, SOM is highest in the topsoil and generally higher in the more acid BLT than in LKS. The $\mathrm{CEC}_{\mathrm{e}}$ is more variable at the more organic-rich BLT than at LKS. Generally, exchangeable acidity is higher at BLT than at LKS. This is in agreement with the higher $\mathrm{pH}$ at LKS than at BLT.

Aluminium ( $\mathrm{Al})$, Iron $(\mathrm{Fe})$ and Manganese $(\mathrm{Mn})$ content in soil is dependent on the rock from which the soil parent material was derived and on the processes of weathering. $\mathrm{Al}, \mathrm{Fe}$ and $\mathrm{Mn}$ are the abundant metallic elements (e.g. $\mathrm{Al}_{2} \mathrm{O}_{3}, 15.9 \% ; \mathrm{FeO}, 9.1 \%$; $\mathrm{MnO}, 0.1 \%$ ) in the continental crust (Taylor and McLennan, 1985). They occur in soils in various operationally defined forms. In addition to those mentioned earlier, there are crystalline forms, but these were not determined in this study. Both pedogenesis and nature of parent material influenced the levels of these metals in surface soil horizons (Dudas and Pawlak, 1977). One of the most important factors that determine the biological availability of a metallic element is its binding to soil constituents (Brennan, 1992). Al, Fe and $\mathrm{Mn}$ in these pools are less available although weathering processes in soils and bedrock may make elements from these pools available in the future. Following changes in environmental conditions such as $\mathrm{pH}$, ionic strength and oxido-reduction processes, metals may become available or thus potentially toxic.

Mean percent distribution of amount of various $\mathrm{Al}, \mathrm{Fe}$ and $\mathrm{Mn}$ forms in soils from the two Hunan catchments was showed in Fig. 2. From Fig. 2, one can be found that exchangeable forms and weakly organically bound forms of $\mathrm{Fe}, \mathrm{Al}$ and $\mathrm{Mn}$ are much smaller than strongly organically bound forms and amorphous and organic forms, except for strongly organically bound form $\mathrm{Mn}\left(\mathrm{Mn}_{\mathrm{p}}\right)$ which is smaller than exchangeable forms and weakly organically bound forms. $\mathrm{Al}_{\mathrm{ex}}$ ranges from $1.46 \mathrm{cmol}_{\mathrm{c}} \mathrm{kg}^{-1}$ in a subsoil horizon to $6.90 \mathrm{cmol}_{\mathrm{c}} \mathrm{kg}^{-1}$ in an organic soil horizon. $\mathrm{Al}_{\mathrm{c}}$ is between 2.0 and 4.5 times $\mathrm{Al}_{\mathrm{ex}} . \mathrm{Al}_{\mathrm{ox}}$ ranges from $0.54 \mathrm{cmol}_{\mathrm{c}} \mathrm{kg}^{-1}$ in a subsoil horizon to $2.02 \mathrm{cmol}_{\mathrm{c}} \mathrm{kg}^{-1}$ in an organic soil horizon. The sizes of the Al-pools in the soils in the two catchments are in the same range as in the acidic forest soils in Chongqing and Guiyang (Liao et al., 1997) and in acidic forest soils in Europe and North America (Berggren and Mulder, 1995; Koptsik and Koptsik, 1995; Koptsik and Silaeva, 1996). The concentration of exchangeable $\mathrm{Fe}$ is low, which may limit the availability of this important plant nutrient (Wang et al., 1989). However, Fe in less available pools is abundant. Because there are significant correlations between Fe-pools and Al-pools (Fig. 5), it seems likely that

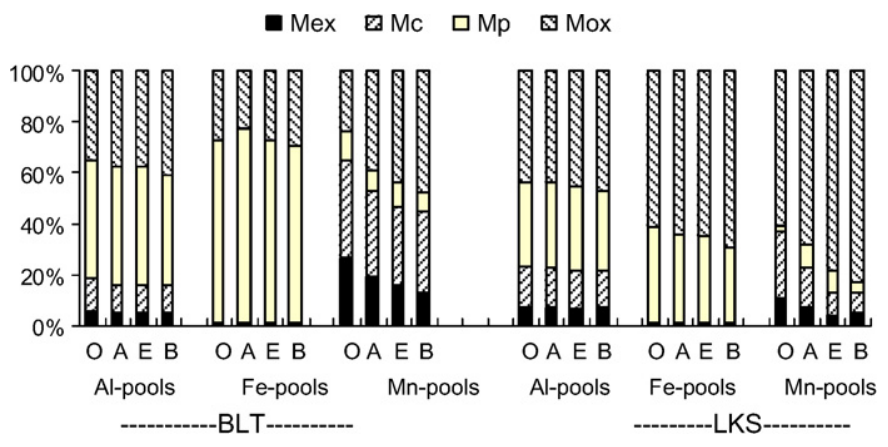

Fig. 2. Mean percent distribution of Amount of various Aluminium, Iron and Manganese forms in soil profiles from the two Hunan catchments. $\left(\mathrm{M}_{\mathrm{ex}}\right.$ denotes exchangeable forms, $\mathrm{M}_{\mathrm{c}}$ : weakly organically bound forms; $\mathrm{M}_{\mathrm{p}}$ : strongly organically bound forms; $\mathrm{M}_{\mathrm{ox}}$ : amorphous and organic forms; O, A, E and B stand for four soil generic horizons.) 
large release of available nutritional $\mathrm{Fe}$ will be accompanied with high release of potentially toxic $\mathrm{Al}$. The concentrations of $\mathrm{Mn}$-pools vary significantly. $\mathrm{Mn}_{\mathrm{ex}}$ ranges from $0.063 \mathrm{mmol}_{\mathrm{c}} \mathrm{kg}^{-1}$ to $1.73 \mathrm{mmol}_{\mathrm{c}} \mathrm{kg}^{-1}$. $\mathrm{Mn}_{\mathrm{c}}$ is between $0.32 \mathrm{mmol}_{\mathrm{c}} \mathrm{kg}^{-1}$ and $2.87 \mathrm{mmol}_{\mathrm{c}} \mathrm{kg}^{-1}$. $\mathrm{Mn}_{\mathrm{ox}}$ ranges from $0.087 \mathrm{mmol}_{\mathrm{c}} \mathrm{kg}^{-1}$ to $8.71 \mathrm{mmol}_{\mathrm{c}} \mathrm{kg}^{-1}$.

Al-pools are larger in the more acid BLT soils than at LKS, but Mn-pools are smaller in the more acid BLT soils than at LKS and for Fe-pools, $\mathrm{Fe}_{\mathrm{ex}}$ and $\mathrm{Fe}_{\mathrm{c}}$ are larger (but $\mathrm{Fe}_{\mathrm{ox}}$ smaller) in BLT (Table 1). The spatial variations in sizes of the $\mathrm{Al}$-, $\mathrm{Fe}$ - and $\mathrm{Mn}$-pools are considerable in the two catchments. The order of magnitude were generally in the order of amorphous and organic forms $\left(\mathrm{Al}_{\mathrm{ox}}, \mathrm{Fe}_{\mathrm{ox}}\right.$ and $\left.\mathrm{Mn}_{\mathrm{ox}}\right)>$ weakly organically bound forms $\left(\mathrm{Al}_{\mathrm{c}}, \mathrm{Fe}_{\mathrm{c}}\right.$ and $\left.\mathrm{Mn}_{\mathrm{c}}\right)>$ exchangeable forms $\left(\mathrm{Al}_{\mathrm{ex}} \mathrm{Fe}_{\mathrm{ex}}\right.$, and $\left.\mathrm{Mn}_{\mathrm{ex}}\right)$ except $\mathrm{Mn}_{\mathrm{ox}}$ variable in BLT. Exchangeable forms $\left(\mathrm{Al}_{\mathrm{ex}}\right.$ $\mathrm{Fe}_{\mathrm{ex}}$, and $\left.\mathrm{Mn}_{\mathrm{ex}}\right)$ are higher in topsoils in the two cachments as compared those in subsoils.
4.2. Correlations between amount of $\mathrm{Al}$-, $\mathrm{Fe}$ - and Mn-pools and soil properties (LOI and pH values) in soils from the two catchments

Conceptually, the amount of soil organic matter is a key parameter for describing the variation in exchangeable and organically bound pools. A prerequisite is that the soils are acid enough to allow significant mobilization of $\mathrm{Al}$ and $\mathrm{Fe}$ from other pools. Acidic atmospheric deposition may facilitate such leaching of $\mathrm{Al}$ and $\mathrm{Fe}$ in acid-sensitive regions (Driscoll et al., 1994; Berggren and Mulder, 1995) since minerals such as $\mathrm{Al}$ (Fe)-(hydro)oxy compounds dissolve more easily in acid water. Complying with these postulations we find that the Al- and Fe-pools are clearly correlated to the LOI (Figs. 3 and 5). From Figs. 3 and 4 we also found that there were generally smaller $\mathrm{Al}(\mathrm{Fe})$-pools and LOI in LKS than in BLT. Reasonably most of Al (Fe)-pools in soils exist mainly in $\mathrm{Al}(\mathrm{Fe})-\mathrm{SOM}$ complex
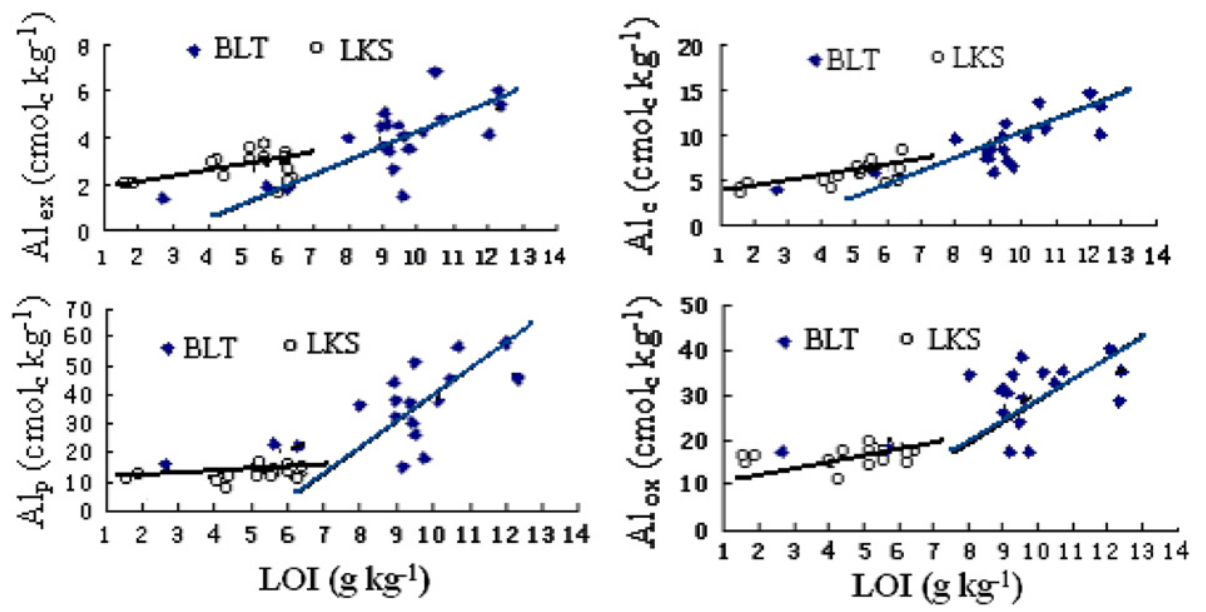

Fig. 3. The relationship between Al-pools and LOI in soils from the two Hunan catchments. (Al-pools were highly linearly correlation with LOI. The linear regressions were significant, i.e. $p \leqslant 0.05$.)
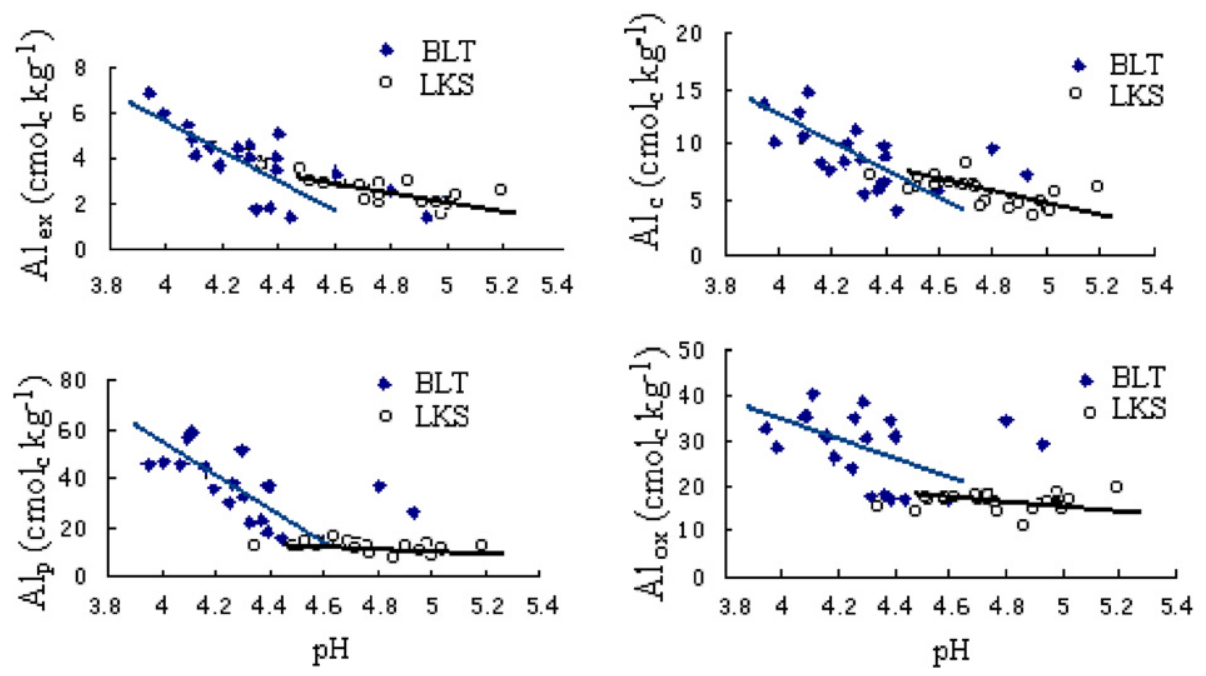

Fig. 4. The correlations between Al-pools and soil $\mathrm{pH}$ values in soils from the two Hunan catchments. (Al-pools were highly linearly correlation with soil $\mathrm{pH}$ values. The linear regressions were significant, i.e. $p \leqslant 0.05$.) 

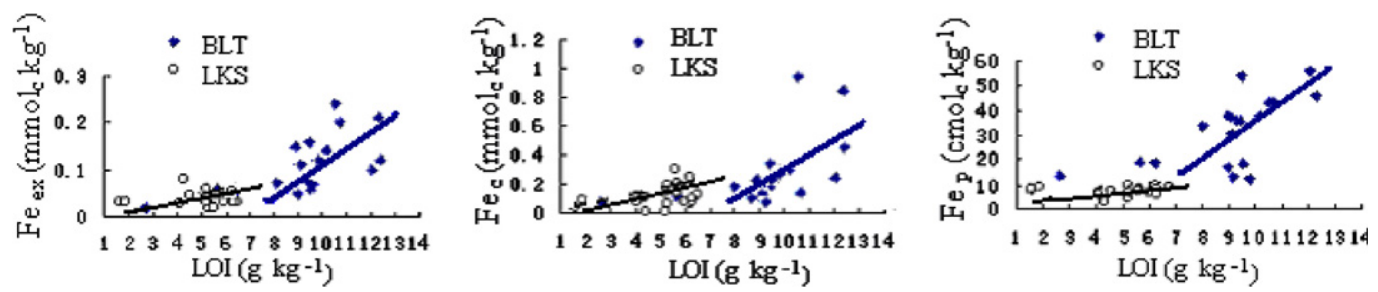

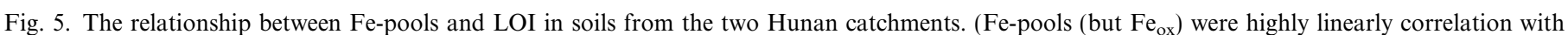
LOI. The linear regressions were significant, i.e. $p \leqslant 0.05$.)

forms. From Table 1, we also found that Fe- or Al-pools/ LOI ratios increase with soil depth although $\mathrm{Fe}$ - and $\mathrm{Al}-$ pools and LOI decrease with the depth. Conceptually, pedogenic processes result in increasing metal/carbon ratios with increasing depth. Because the input of organic matter $(\mathrm{OM})$ in O-horizon is great; And the dissolved OM (i.e. humus) bound with the increasing amounts of $\mathrm{Fe}$ and $\mathrm{Al}$ was transported with depth until the complex becomes insoluble and sorbs. April et al. (2004) reported soil solutions draining the $\mathrm{O}$ horizon showed elevated fluxes and concentrations of organic and particulate $\mathrm{Al}$, while concentrations and fluxes of inorganic monomeric $\mathrm{Al}$ were low. It seems likely that $\mathrm{Al}$ is largely mobilized from the forest floor by organic acid dissolution of soil minerals. Generally, OM is related with soil acidity. Deductively there is a positive relationship between Aland Fe-pools and soil acidity. In agreement with this, Al $(\mathrm{Fe})$-pools (except $\mathrm{Fe}_{\mathrm{ox}}$ ) were highly linearly correlation with soil $\mathrm{pH}$ values in soils from the two Hunan catchments (see Figs. 4 and 6). Manganese was slightly bound to organic matter (Roux et al., 1998). No significant correlation between $\mathrm{Mn}$-pools (except for $\mathrm{Mn}_{\mathrm{ox}}$ ) and $\mathrm{OM}$ was observed. $\mathrm{Mn}_{\mathrm{ox}}$ concentration strongly decreases with the decrease of OM, and there clearly was significant correla- tion between $\mathrm{Mn}_{\mathrm{ox}}$ and LOI in catchment BLT as described in Fig. 7(a), however other speciation of this element does not seem to be affected by the presence of OM. Thus this indicated that soil organic matter does not exert an important control on Mn speciation in studied catchments. However, we do not exclude the possibility of $\mathrm{Mn}$ being partially binded to organic matter. Figs. 4 and 6 also showed there are the correlations between amount of Aland $\mathrm{Fe}$-pools and soil $\mathrm{pH}$ values in soils from the two catchments. Al- and Fe-pools were highly linearly correlation with soil $\mathrm{pH}$ values. From Figs. 4 and 6 we also found that there were generally smaller $\mathrm{Al}(\mathrm{Fe})$-pools and higher $\mathrm{pH}$ values in LKS than in BLT. The chemistry of Mn in soils and soil solution is governed by $\mathrm{pH}$ and redox potential (Flessa and Fischer, 1992). There were a significantly linearly negative correlation $(n=20, p \leqslant 0.05)$ between $\mathrm{Mn}_{\mathrm{ex}}$ and $\mathrm{pH}$ values in LKS (see Fig. 7(b)) and a significantly linearly positive correlation $(n=20, p \leqslant 0.05)$ between $\mathrm{Mn}_{\mathrm{ox}}$ and $\mathrm{pH}$ values in LKS (see Fig. 7(c)), but no significant correlations was observed between Mn-pools and $\mathrm{pH}$ values in BLT. The differences between the two catchments may be related to soil redox potential that may be associated with different vegetations, parent materials, climate conditions etc. in small catchments (see
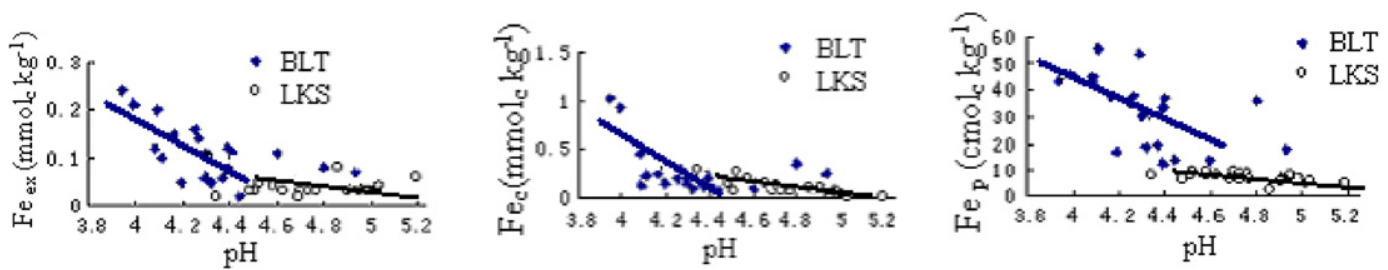

Fig. 6. The correlations between Fe-pools and soil $\mathrm{pH}$ values in soils from the two Hunan catchments. (Fe-pools (except for Fe $\mathrm{ox}_{\mathrm{x}}$ ) were highly linearly correlation with soil $\mathrm{pH}$ values. The linear regressions were significant, i.e. $p \leqslant 0.05$.)
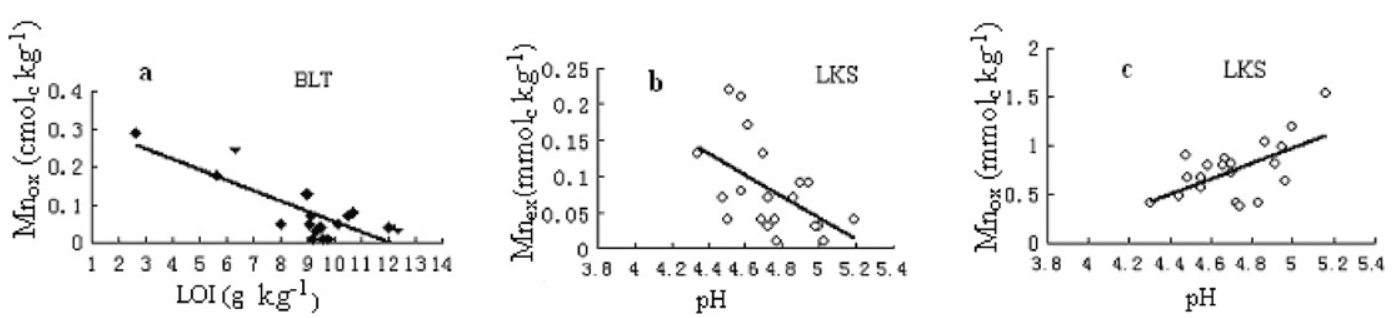

Fig. 7. Correlations between Mn-pools and LOI or soil $\mathrm{pH}$ values in soils from the two Hunan catchments. (Correlation between Mn ${ }_{\mathrm{ox}}$ and LOI in BLT, between $\mathrm{Mn}$-pools $\left(\mathrm{Mn}_{\mathrm{ox}}, \mathrm{Mn}_{\mathrm{ex}}\right)$ and soil $\mathrm{pH}$ values in LKS. The linear regressions were significant, i.e. $p \leqslant 0.05$.) 
Section 2). Generally, the release of $\mathrm{Mn}, \mathrm{Al}$ and $\mathrm{Fe}$ is strongly $\mathrm{pH}$ dependent. It was therefore concluded that $\mathrm{Al}, \mathrm{Fe}$ and $\mathrm{Mn}$ mobilization by acid deposition is involved.

The atmospheric deposition could be an important source of $\mathrm{Al}, \mathrm{Fe}$ and $\mathrm{Mn}$ in a polluted area, however, it may be a less important source than internal release (e.g. weathering, mineralization, desorption from soil/sediment surfaces). Acidic atmospheric deposition may facilitate leaching of $\mathrm{Al}, \mathrm{Fe}$ and $\mathrm{Mn}$ in acid-sensitive regions and adversely impact surface water quality (Miller et al., 1983). These effects are particularly evident at high elevations due to increased amounts of precipitation and the scavenging of acidic aerosols by coniferous canopies (Lovett et al., 1982), as well as shallow soils which show limited neutralization of acid inputs (Driscoll et al., 1988). Soluble organic acids from leaf leachate or mineralization of soil organic matter may form aqueous complexes with trace metals (i.e. $\mathrm{Al}, \mathrm{Fe}$ and $\mathrm{Mn}$ ), facilitating transport to the lower mineral soil or to surface water (Turner et al., 1985). Therefore, acidic atmospheric deposition may affect transforming among speciations of Al-, Feand Mn-pools and leaching of soil Al, Fe and Mn, likely, through formation of soluble organo-metal complexes or change of oxidation-reduction conditions.

\subsection{Correlations among amount of Al-, Fe- and Mn-pools in soils from the two catchments}

Fig. 8 showed the relationship among $\mathrm{Al}$-pools. $\mathrm{Al}_{\mathrm{c}}$ is highly linear correlation with $\mathrm{Al}_{\mathrm{ex}} ; \mathrm{Al}_{\mathrm{p}}$ is highly linear correlation with $\mathrm{Al}_{\mathrm{ex}} ; \mathrm{Al}_{\mathrm{ox}}$ is highly linear correlation with $\mathrm{Al}_{\mathrm{ex}} ; \mathrm{Al}_{\mathrm{p}}$ is highly linear correlation with $\mathrm{Al}_{\mathrm{c}} ; \mathrm{Al}_{\mathrm{ox}}$ is highly linear correlation with $\mathrm{Al}_{\mathrm{c}} ; \mathrm{Al}_{\mathrm{ox}}$ is highly linear correlation with $\mathrm{Al}_{\mathrm{p}}$. The linear regressions are significant, i.e. $p \leqslant 0.05, n=20$. Therefore, one of $\mathrm{Al}$ forms varies following change of other $\mathrm{Al}$ forms in soils. Once environment change, such as input of acid rain, an increase of exchangeable Al will occur, which results all Al-pools increase.

Fig. 9 showed the relationship among Fe-pools. $\mathrm{Fe}_{\mathrm{c}}$ is highly linear correlation with $\mathrm{Fe}_{\mathrm{ex}}, \mathrm{Fe}_{\mathrm{p}}$ is highly linear correlation with $\mathrm{Fe}_{\mathrm{ex}}, \mathrm{Fe}_{\mathrm{p}}$ is highly linear correlation with $\mathrm{Fe}_{\mathrm{c}}$. The linear regressions are significant, i.e. $p \leqslant 0.05$. But Fe $e_{\text {ox }}$ is not correlation with other $\mathrm{Fe}$ forms. Lindsay (1991) reported that solubility of iron is largely controlled by ferric oxides, especially ferrihydrite and amorphous ferric hydroxide and the formation of chelated iron drived from soil organic matter or microbial production of siderophores. Many reactions are involved in the solubility of $\mathrm{Fe}$ in soil, but hydrolysis and complexed species appear to be most the significant. Fig. 10 showed the relationship between Fe-pools and Al-pools both in BLT and LKS. $\left(\mathrm{Fe}_{\mathrm{ex}}\right.$ is highly linear correlation with $\mathrm{Al}_{\mathrm{ex}} ; \mathrm{Fe}_{\mathrm{c}}$ is highly linear correlation with $\mathrm{Al}_{c} ; \mathrm{Fe}_{\mathrm{p}}$ is highly linear correlation with $\mathrm{Al}_{\mathrm{p}}$. The linear regressions are significant, i.e. $p \leqslant$ 0.05.) However, no direct correlation is observed between $\mathrm{Mn}$-pools and $\mathrm{Fe}$-pools. $\mathrm{Fe}_{\mathrm{ex}}$ correlating with $\mathrm{Al}_{\mathrm{ex}}$ may be explained by the fact that $\mathrm{Fe}_{\mathrm{ex}}$ and $\mathrm{Al}_{\mathrm{ex}}$ both correlate with the CEC.
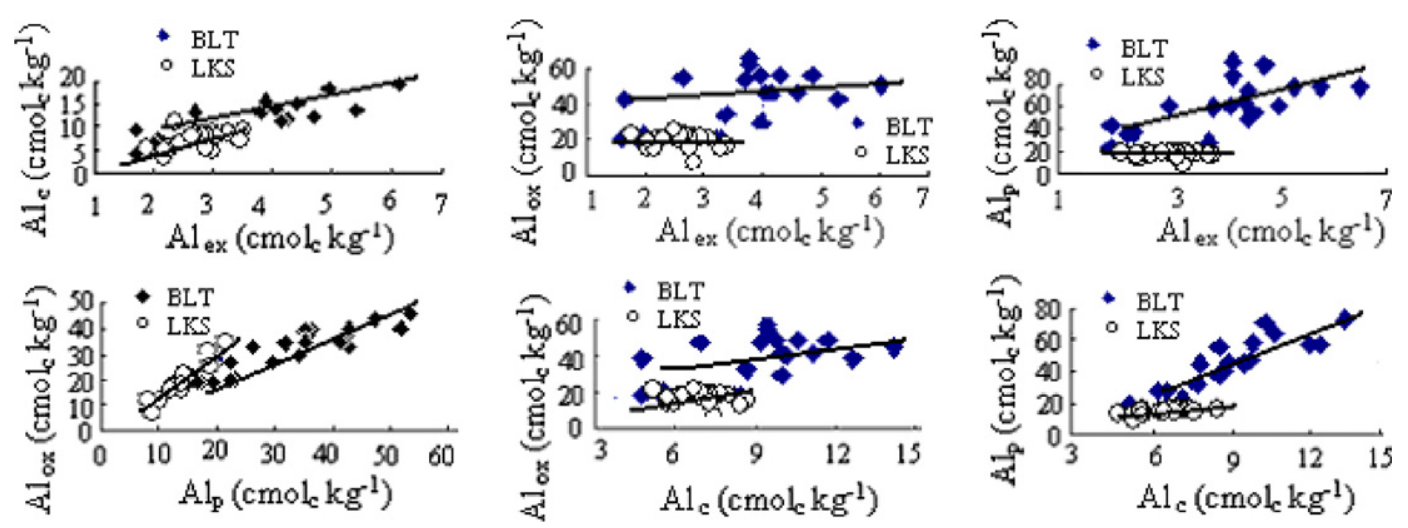

Fig. 8. The relationship among $\mathrm{Al}$-pools. ( $\mathrm{Al}_{\mathrm{c}}$ is highly linear correlation with $\mathrm{Al}_{\mathrm{ex}}, \mathrm{Al}_{\mathrm{p}}$ is highly linear correlation with $\mathrm{Al}_{\mathrm{ex}}$, $\mathrm{Al}_{\mathrm{ox}}$ is highly linear correlation with $\mathrm{Al}_{\mathrm{ex}}, \mathrm{Al}_{\mathrm{p}}$ is highly linear correlation with $\mathrm{Al}_{\mathrm{c}}, \mathrm{Al}_{\mathrm{ox}}$ is highly linear correlation with $\mathrm{Al}_{\mathrm{c}} ; \mathrm{Al}_{\mathrm{ox}}$ is highly linear correlation with $\mathrm{Al}_{\mathrm{p}}$. The linear regressions are significant, i.e. $p \leqslant 0.05$.)
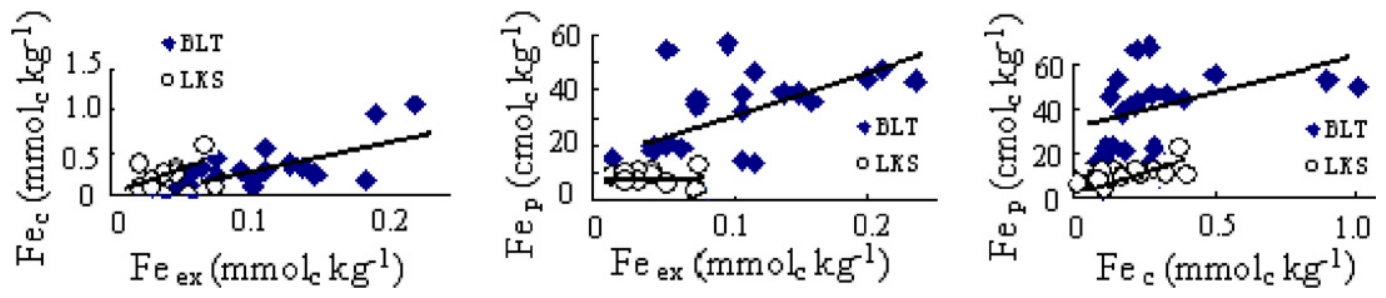

Fig. 9. The relationship among Fe-pools. ( $\mathrm{Fe}_{\mathrm{c}}$ is highly linear correlation with $\mathrm{Fe}_{\mathrm{ex}}, \mathrm{Fe}_{\mathrm{p}}$ is highly linear correlation with $\mathrm{Fe}_{\mathrm{ex}}$, $\mathrm{Fe}_{\mathrm{p}}$ is highly linear correlation with $\mathrm{Fe}_{\mathrm{c}}$. The linear regressions are significant, i.e. $p \leqslant 0.05$.) 

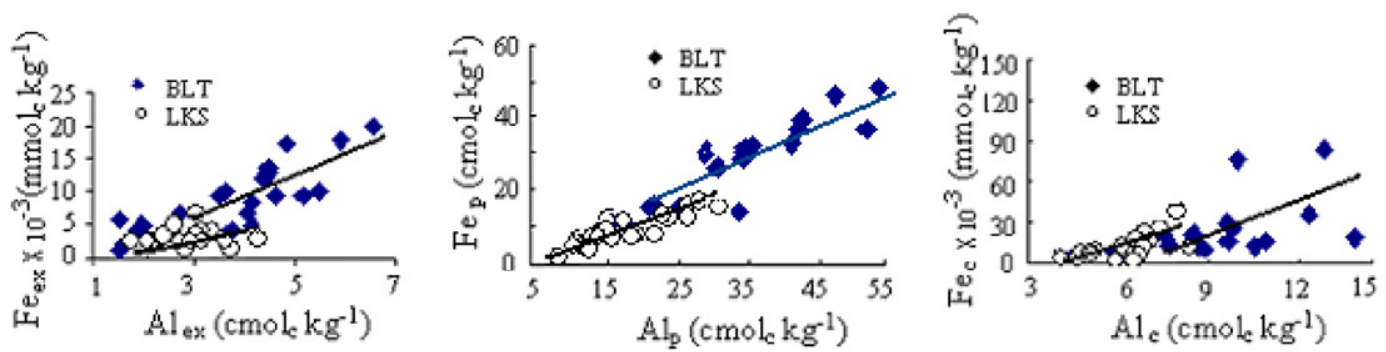

Fig. 10. The relationship between $\mathrm{Fe}$-pools and $\mathrm{Al}$-pools. $\left(\mathrm{Fe}_{\mathrm{ex}}\right.$ is highly linear correlation with $\mathrm{Al}_{\mathrm{ex}} ; \mathrm{Fe}_{\mathrm{c}}$ is highly linear correlation with $\mathrm{Al}_{\mathrm{c}}$; $\mathrm{Fe}_{\mathrm{p}}$ is highly linear correlation with $\mathrm{Al}_{\mathrm{p}}$. The linear regressions are significant, i.e. $p \leqslant 0.05$.)

There were significant correlations between Al-pools and the corresponding Fe-pools except between the amorphous $\mathrm{Fe}_{\text {ox }}$ and $\mathrm{Al}_{\text {ox }}$ in the two catchments. Under acid deposition, the availability of the nutrient Fe increased with the amount of dissolved $\mathrm{Al}$, which was potentially toxic, in the two catchments. For Mn-pools, pH may much influence the amorphous $\mathrm{Mn}_{\mathrm{ox}}$, but no significant correlations are observed between soil $\mathrm{pH}$ and exchangeable $\mathrm{Mn}\left(\mathrm{Mn}_{\mathrm{ex}}\right)$. There are no significant correlations between exchangeable $\mathrm{Al}\left(\mathrm{Al}_{\mathrm{ex}}\right)$ and $\mathrm{Mn}_{\mathrm{ex}}$, exchangeable $\mathrm{Fe}\left(\mathrm{Fe}_{\mathrm{ex}}\right)$ and $\mathrm{Mn}_{\mathrm{ex}}$ in this work, indicating potentially toxic $\mathrm{Mn}$ increase seldom accompanying with $\mathrm{Al}$ increase in the two catchments. This is in agreement with Pontér et al. (1992) who argued that Fe-pools do not exert an important control on $\mathrm{Mn}$ transport. And on acid soils Mn-toxicity is particularly prevalent with decreasing partial pressure of $\mathrm{O}_{2}$ (Zorn and Prauße, 1993). However, the reasons about no significant correlations between $\mathrm{Mn}_{\mathrm{ex}}$ and $\mathrm{Al}_{\mathrm{ex}}\left(\mathrm{Fe}_{\mathrm{ex}}\right)$ are uncertain.

\section{Conclusions}

The study approach in a small catchment scale is an effective tool to facilitate understanding the transport and cycling of $\mathrm{Al}, \mathrm{Fe}$ and $\mathrm{Mn}$ in forest ecosystems. Interactions between these metals and organisms are of particular interest in environmental chemistry because of potential nutrient deficiencies and toxicity (Simkiss and Taylor, 1989). Unfortunately, mechanisms of trace metal bioavailability vary from organism to organism and metal to metal. In natural media, $\mathrm{Al}, \mathrm{Fe}$ and $\mathrm{Mn}$ undergo numerous changes during their transport due to dissolution, precipitation, leaching, ion-exchange and sorption phenomena. Movability and bioavailability of $\mathrm{Al}, \mathrm{Fe}$ and $\mathrm{Mn}$ strongly depend on their speciations. Acidic atmospheric deposition may affect transforming among speciations of Al-, Fe- and $\mathrm{Mn}$-pools and leaching of soil $\mathrm{Al}, \mathrm{Fe}$ and $\mathrm{Mn}$ through formation of soluble organo-metal complexes or change of oxidation-reduction conditions. $\mathrm{Mn}_{\mathrm{ex}}$ and $\mathrm{Mn}_{\mathrm{ox}}$ were highly linearly correlation with soil $\mathrm{pH}$ values at LKS but at BLT. Under acid deposition, the availability of the nutrient $\mathrm{Fe}$ increased with the amount of dissolved $\mathrm{Al}$, which was potentially toxic, in the two catchments. There are no significant correlations between $\mathrm{Al}_{\mathrm{ex}}$ and $\mathrm{Mn}_{\mathrm{ex}}, \mathrm{Fe}_{\mathrm{ex}}$ and $\mathrm{Mn}_{\mathrm{ex}}$ in this work, indicating potentially toxic $\mathrm{Mn}$ increase seldom accompanying with $\mathrm{Al}$ increase in the two catchments.

However, a number of factors complicate the picture. Speciations of Al-, Fe- and Mn-pools depend greatly on the geochemical structure of metal-rich metamorphic rocks and environmental conditions such as the redox potential, electrical conductivity (EC). Mn-pools also were affected by industrial wastes and pesticides which contain Mn. Furthermore, industrial and agricultural activities can change the distribution of Al-, Fe- and Mn-pools.

So far, no clear signs of damage to vegetation have been documented due to the change Al- and Mn-pools under acid deposition. However, because acidification is likely to occur in a long-term perspective, further studies and investigations in more catchments are needed for a better understanding of the effects of acid deposition on elemental biogeochemistry in the forest ecosystem.

\section{Acknowledgements}

The authors acknowledge financial support from Chinese Ministry of Education ([2000]65-HN005). We thank Associate Professor Boqing Tie, Dr. Yong Zhang and Dr. Min Zeng for collecting field samples. Professor Rolf D. Vogt is thanked for his valuable comments on the manuscript.

\section{References}

April, R., Keller, D., Driscoll, C.T., 2004. Smectite in spodosols from the Adirondack Mountains of New York. Clay Minerals 39, 99-113.

Berggren, D., Mulder, J., 1995. The role of organic matter in controlling aluminium solubility in acidic mineral soil horizons. Geochem. Acta 59, 4167-4180.

Binkley, D., 1986. Forest Nutrition Management. John Wiley \& Sons, New York, NY.

Brennan, R.F., 1992. The relationship between critical concentrations properties of south-western Australian soils responsive to applied zinc. Commun. Soil Sci. Plant Anal. 23, 747-759.

Chen, M., Tan, J., Sun, F., 1995. Research on the mechanisms of sulfate adsorption in quaternary red soil in southern Hunan. Environ. Chem. 14, 129-133 (in Chinese).

Driscoll, C.T., Fuller, R.D., Simone, D.M., 1988. Longitudinal variations in trace metal concentrations in a northern forested ecosystem. J. Environ. Qual. 17, 101-107.

Driscoll, C.T., Otton, J.K., Iverfeldt, Å., 1994. SCOPE 51, Biogeochemistry of small catchments - a tool for environmental research. Moldan, B., Cerny, J., (Eds.) Chapter 3: Atmospheric Chemical Input to Small 
Catchments. Chapter 13: Trace Metals Speciation and Cycling. Available from: $<$ http://www.icsu-scope.org $>$.

Dudas, M.J., Pawlak, S., 1977. Heavy metals in cultivated soils and cereal crops in Alberta. Can. J. Soil Sci. 57, 329-339.

Fernandez, I.J., 1985. Acid deposition and forest soils: potential impacts and sensitivity. In: Adams, D.D., Page, W.P. (Eds.), Acid Deposition-Environmental, Economic, and Policy Issues. Plenum Press, New York, NY, pp. 223-239.

Flessa, H., Fischer, W.R., 1992. Plant induced changes in the redox potential of rice rhizospheres. Plant Soil 143, 55-60.

Hendershot, W.H., Duquette, M., 1986. A simple barium chloride method for determining cation exchange capacity and exchangeable cations. Soil Sci. Soc. Am. J. 50, 605-608.

Hendershot, W.H., Courchesne, F., Schemenauer, R.S., 1992. Soil acidification along a topographic gradient on Roundtop Mountain, Quebec, Canada. Water Air Soil Pollut. 61, 235-242.

IMPACTS, 2003. Integrated monitoring program on acidification of chinese terrestrial systems. Available from: $<$ http://www.impacts.net.cn/>.

ISO, 1994. Soil quality - determination of $\mathrm{pH}$. International standard, ISO10390, 5p.

Jou, A.S.R., Kamprath, E.J., 1979. Copper chloride as an extractant for estimating the potentially reactive aluminium pool in acid soils. Soil Sci. Soc. Am. J. 43, 35-38.

Koptsik, G., Koptsik, S., 1995. Critical loads of acid deposition for forest ecosystems in the Kola Peninsula. Water, Air Soil Pollut. 85, 25532558.

Koptsik, G.N., Silaeva, E.D., 1996. Buffering capacity of forest litters to acid atmospheric precipitation. Eurasian Soil Sci. 28 (10), 124-136.

Krogstad, T., 1992. Methods in soil analyses. Report 6/92. Department of Soil Science, Agricultural University of Norway.

Liao, B., Li, C., 1989. A study on the buffering mechanism of soils. Environ. Sci. 10, 30-34 (in Chinese).

Liao, B., Seip, H.M., Larssen, T., 1997. Response of two Chinese forest soils to acidic input: leaching experiment. Geoderma 75, 53-73.

Liao, B., Larssen, T., Seip, H.M., 1998. Response of five Chinese forest soils to acidic input: batch experiment. Geoderma 86, 295-316.

Likens, G.E., Driscoll, C.T., Buso, D.C., Mitchell, M.J., Lovett, G.M., Bailey, S.W., Siccama, T.G., Reiners, W.A., Alewell, C., 2002. The biogeochemistry of sulfur at Hubbard Brook. Biogeochemistry 60, 235-316.

Lindsay, W.L., 1991. Iron oxide solubility by organic matter and its effect on iron availability. In: Chen, Y., Hadar, Y. (Eds.), Iron Nutrition and Interactions in Plants. Kluwer Academic, Dordrecht, The Netherlands, pp. 29-36.

Lovett, G.M., Reiners, W.A., Olson, R.K., 1982. Cloud droplet deposition in subalpine balsam fir forests: hydrologic and chemical inputs. Science 218, 1303-1304.

Martin, J.M., Nirel, P., Thomas, A.J., 1987. Sequential extraction techniques: promises and problems. Mar. Chem. 22, 313-341.

Mckeague, J.A., Day, J.H., 1966. Dithionite- and oxalate-extractable Fe and $\mathrm{Al}$ as aids in differentiating various classes of soil. Can. J. Soil Sci. $46,13-22$.

Miller, W.J., McFee, W.W., Kelly, J.M., 1983. Mobility and retention of heavy metals in sandy soils. J. Environ. Qual. 12, 579-586.

Pontér, C., Ingri, J., Boström, K., 1992. Geochemistry of manganise in the Kalix River, northern Sweden. Geochem. Cosmochim. Acta 56, 1485 1494.

Probst, A., Dambrine, E., Viville, D., Pritz, B., 1990. Influence of acid atmospheric inputs on surface water chemistry and mineral fluxes in a declining spruce stand within a small granite catchment (Vosges Massif, France). J. Hydrol. 116, 101-124.

Raubuch, M., Beese, F., Bolger, T., Anderson, J.M., Berg, M.P., Couteaux, M.M., Ineson, P., Mccarthy, F., Splatt, P., Verhoef, H.A., Willison, T., 1998. Acidifying processes and acid-base reactions in forest soils reciprocally transplanted along a European transect with increasing pollution. Biogeochemistry 41, 71-88.

Robarge, W.P., Fernandez, I., 1986. Laboratory analytical techniquesquality Assurance Methods Manual for Forest Response Program. US Environmental Protection Agency and USDA, Forest Service, Washington, DC, 158pp.

Rodhe, H., Grennfelt, P., Wisniewski, J., Agren, C., Bengtsson, G., Johansson, K., Kauppi, P., Kucera, V., Rasmussen, L., Rosseland, B., Schotte, L., Selldén, G., 1995. Acid Reign'95-conference summary statement. Water Air Soil Pollut. 85, 1-14.

Roux, L.L., Roux, S.L., Appriou, P., 1998. Behaviour and speciation of metallic species $\mathrm{Cu}, \mathrm{Cd}, \mathrm{Mn}$ and $\mathrm{Fe}$ during estuarine mixing. Mar. Pollut. Bull. 36 (1), 56-64.

Seip, H.M., Aagaard, P., Angell, V., Eilertsen, O., Larssen, T., Lydersen, E., Mulder, J., Muniz, I.P., Semb, A., Tang, D., Vogt, R.D., Xiao, J., Xiong, J., Zhao, D., Kong, G., 1999. Acidification in China: assessment based on studies at forested sites from Chongqing to Guangzhou. Ambio 28, 522-528.

SEPA, 2001. Information of environment. (in Chinese) 2001.5.28, 146, (9) State Environmental Protection Administration.

Shao, M., 2002. Acid deposition from IMPACT sites; chemistry and variation. Presentation at IMPACTS Mid-term Conference, Beijing, November 2002. Available from: $<$ http://www.impacts.net.cn/ $>$.

Simkiss, K., Taylor, M.G., 1989. Metal fluxes across membranes of aquatic organisms. Rev. Aquat. Sci. 1, 174-188.

Tao, F., Hayashi, Y., Lin, E., 2002. Soil vulnerability and sensitivity to acid deposition in China. Water Air Soil Pollut. 140 (1-4), 247260.

Taylor, S.R., McLennan, S.M., 1985. The continental crust: its composition and evolution blackwell scientific publications. Geoscience. Blackwell, Oxford, 312pp.

Turner, R.S., Wang, D.W., Johnson, A.H., 1985. Biogeochemistry of lead in McDonald's Branch Watershed, New Jersey Pine Barrens. J. Environ. Qual. 14, 305-310.

Van Reeuwijk, L.P. (Ed.), 1995. Procedures for Soil Analysis. ISRIC, Wageningen, The Netherlands, pp. 121-128.

Van Breemen, N., Wright, R.F., 2004. History and prospect of catchment biogeochemistry: a European perspective based on acid rain. Ecology 85 (9), 2363-2368.

Wang, Y.G., Sheng, P.L., Yuan, D.W., 1989. Effects of simulated acid rain on leaching and availability of soil metal ions. Environ. Sci. 9 (2), 22 26 (in Chinese).

Watmough, S.A., Aherne, J., Alewell, C., Arp, P., Bailey, S., Clair, T., Dillon, P., Duchesne, L., Eimers, C., Fernandez, I., Foster, N., Larssen, T., Miller, E., Mitchell, M., Page, S., 2005. Sulphate, nitrogen and base cation budgets at 21 forested catchments in Canada, the United States and Europe. Environ. Monit. Assess. 109 (1-3), 1-36.

Xue, N., Seip, H.M., Liao, B., Vogt, R.D., 2003. Studies of acid deposition and its effects in two small catchments in Hunan, China. Hydrol. Earth Sys. Sci. 3, 399-410.

Zhao, D., Larssen, T., Zhang, D., Gao, S., Vogt, R.D., Seip, H.M., Lund, O.J., 2001. Acid deposition and acidification of soil and water in the Tie Shan Ping area, Chongqing, China. Water Air Soil Pollut. 130, 1733-1738.

Zorn, Prauße, 1993. Z. Pflanzenern. Boden 156, 371-376. 